\title{
Szolidszerv-transzplantáció után kialakuló de novo gyulladásos bélbetegség gyermekkorban
}

\author{
Boros Kriszta Katinka dr. - Kelen Kata dr. - Reusz György dr. \\ Sallay Péter dr. - Szabó Attila dr. - Dezsőfi Antal dr.
}

Semmelweis Egyetem, Általános Orvostudományi Kar, I. Gyermekgyógyászati Klinika, Budapest

\begin{abstract}
A gyulladásos bélbetegség (inflammatory bowel disease, IBD) incidenciája folyamatosan nő, etiológiája egyelőre ismeretlen. Kezelésében gyakran alkalmazunk immunszuppresszív, illetve immunmoduláns szereket. Egyes esetekben azonban szolidszerv-transzplantációt követően, folyamatos immunszuppresszív kezelés mellett is megfigyelhető de novo IBD kialakulása. Célunk az volt, hogy Klinikánk beteganyagából összesítsük azon eseteket, amelyekben szolid szerv (máj, vese, tüdő) transzplantációját követően de novo IBD alakult ki. A transzplantációt megelőzően szklerotizáló cholangitis miatt gondozott betegeket kizártuk. A Klinikánkon gondozott, szolid szerv transzplantációján (179 máj, 197 vese, 29 tüdő) átesett betegek közül 4 (2 máj- és 2 vesetranszplantált) gyermeknél alakult ki de novo IBD. A transzplantációhoz vezető alapbetegségek biliaris atresia, polycystás vese és Denys-Drash-szindróma voltak. A transzplantációt követő immunszuppresszív terápia mind a 4 esetben tartalmazott szisztémásszteroid- és takrolimuszkezelést, emellett 3 esetben mikofenolát-mofetil (MMF)-terápiát is. A kivizsgálást indikáló főbb tünetek a haematochesia, hasmenés, fáradékonyság és fogyás voltak. A családi anamnézis l esetben volt pozitív. A de novo IBD diagnózisának felállítását követően mind a 4 betegnél az addigi immunszuppressziós terápia módosításra került. Összességében elmondható, hogy a szolidszerv-transzplantációt követő de novo IBD kialakulása ritka, etiológiája tisztázatlan. Az irodalom felveti az alkalmazott immunszuppresszív szerek (takrolimusz és MMF), illetve infekciók etiológiai szerepét, de az is felmerül, hogy a de novo IBD olyan önálló entitás, mely elkülönül a klasszikus IBD kategóriáitól. Klinikai szempontból fontos a tünetek hátterében álló betegség tisztázása, hiszen a prezentációs tüneteknek megfelelő, a differenciáldiagnosztika során felmerülő egyéb betegségek terápiája merőben eltér. A megfelelő terápia hozzájárulhat a transzplantált betegek morbiditásának és mortalitásának csökkentéséhez.

Orv Hetil. 2021; 162(18): 720-726.
\end{abstract}

Kulcsszavak: szolidszerv-transzplantáció, de novo gyulladásos bélbetegség, gyulladásos bélbetegség, immunszuppresszió

\section{De novo inflammatory bowel disease in children after solid organ transplantation}

The incidence of inflammatory bowel disease (IBD) is increasing, however, the aetiology is still unknown. The therapy consists of immunosuppressants and immunomodulators. In some cases, despite the continuous immunosuppressant therapy, de novo IBD develops. Our aim was to evaluate patients diagnosed with de novo IBD after solid organ (liver, kidney, or lung) transplantation. Patients treated with sclerosing cholangitis prior to liver transplantation were excluded. 4 patients (two kidney and two liver transplants) were diagnosed with de novo IBD. The underlying diseases leading to transplantation were biliary atresia, polycystic kidney, and Denys-Drash syndrome. All patients received systemic steroid and tacrolimus treatment, and 3 patients ( 2 kidney and 1 liver transplant) also received mycophenolate mofetil (MMF). The main symptoms indicative of de novo IBD were haematochezia, diarrhoea, fatigue, and weight loss. Family history for IBD was positive in 1 case. Following the diagnosis of IBD, immunosuppressive therapy was modified. Overall, the development of de novo IBD following solid organ transplantation is quite rare, and its aetiology is unknown. According to the literature, immunosuppressants (tacrolimus and MMF) and infections play a role in the pathomechanism, but it seems that de novo IBD is a separate entity from the classical IBD categories. From a clinical point of view, it is important to elucidate the underlying disease of the symptoms, as the treatment of other diseases that arise during differential diagnosis according to the presentation symptoms is very different. Appropriate therapy can help reduce morbidity and mortality in transplant patients. 
Keywords: solid organ transplantation, de novo inflammatory bowel disease, inflammatory bowel disease, immunosuppression

Boros KK, Kelen K, Reusz Gy, Sallay P, Szabó A, Dezsőfi A. [De novo inflammatory bowel disease in children after solid organ transplantation]. Orv Hetil. 2021; 162(18): 720-726.

(Beérkezett: 2020. szeptember 23.; elfogadva: 2020. november 13.)

\section{Rövidítések}

5-ASA = 5-aminoszalicilsav; ANCA = antineutrofil citoplazmatikus antitest; ASCA = Saccharomyces cerevisiae elleni antitest; $\mathrm{AZA}=$ azatioprin CyA $=$ ciklosporin $-\mathrm{A} ; \mathrm{DAMP}=($ damage associated molecular patterns) károsodáshoz társult molekuláris mintázat; DNS = dezoxiribonukleinsav; HUPIR = $($ Hungarian Paediatric IBD Registry) Magyar Gyermekkori IBD Regiszter; IBD = gyulladásos bélbetegség; IBD-U = (inflammatory bowel disease unclassified) „nem besorolható” IBD; $\mathrm{IL}=$ interleukin; INR = (international normalized ratio $)$ nemzetközi normalizált ráta; $\mathrm{MMF}=$ mikofenolát-mofetil; $\mathrm{MR}=$ mágneses rezonancia; PAMP $=$ (pathogen-associated molecular patterns), patogénhez társult molekuláris mintázat; PCR = (polymerase chain reaction) polimeráz-láncreakció; VCAM = (vascular cell adhesion molecule) vascularis sejtadhéziós molekula

A gyulladásos bélbetegség (inflammatory bowel disease, IBD) a gastrointestinalis rendszert érintő krónikus, gyulladásos megbetegedés, melyhez 3 betegség sorolható: Crohn-betegség (Crohn's disease), colitis ulcerosa (ulcerative colitis) és a nem besorolt colitis (indeterminate colitis). A betegség pontos etiológiája máig tisztázatlan, de kialakulásában szerepet játszanak genetikai és környezeti faktorok, immunológiai tényező́k és a bélmikrobiom [1].

Az IBD kezelésében az immunszuppresszív terápia fontos szerepet játszik. Előfordulhat azonban, hogy szolid szerv transzplantációját követően, immunszuppreszszív terápia mellett a már korábban is meglévő IBD kiújul, illetve korábban jelen nem lévő IBD alakul ki, hajlamosító társbetegség (például szklerotizáló cholangitis) nélkül.

A de novo IBD etiológiája az IBD-éhez hasonlóan tisztázatlan, felmerül azonban többek közt a poszttranszplantációs időszakban előforduló cytomegalovirus- [2] és Clostridium difficile fertőzés, a sebészi beavatkozás következtében megváltozott anatómia és a mikrobiomban történő változások [3] oki szerepe, továbbá molekuláris szinten a DAMP-ok (damage-associated molecular patterns) és a PAMP-ok (pathogen-associated molecular patterns) szerepe [4], illetve különböző immunszuppresszánsok hatásai [5], kiemelve a mellékhatásként colitis kialakulására hajlamosító mikofenolát-mofetilt (MMF) $[6,7]$. Terápiájában a leginkább aminoszalicilátok, azatioprin (AZA), szisztémás kortikoszteroidok, budezonid használatos, de esettanulmányként leírták az infliximab hatásosságát is [3].

Magyarországon a gyermekkori szervtranszplantáció az elmúlt évtizedek egyik sikertörténete. Vesetranszplantáció 1981, májtranszplantáció 1988, tüdőtranszplantáció 1996 óta érhető el a magyar gyermekek számára [8]. A vesetranszplantált gyermekek gondozásában mind a négy egyetemi gyermekklinika részt vesz, a máj- és tüdőtranszplantált betegek gondozása azonban kizárólag a Semmelweis Egyetem I. Gyermekgyógyászati Klinikáján történik.

A jelen összefoglaló célja az volt, hogy retrospektíven összesítse az 1981 és 2020 között, összesen 405, szolid szerv transzplantációján (179 máj, 197 vese, 29 tüdő) átesett gyermek közül azokat, akiknél a transzplantációt követóen de novo IBD-t diagnosztizáltunk. Tekintettel a colitis ulcerosa és a szklerotizáló cholangitis gyakori társulására, a jelen összefoglalóból a transzplantáció előtt IBD-vel diagnosztizált, illetve a szklerotizáló cholangitis miatt transzplantált gyermekeket kizártuk.

\section{Esetbemutatások}

\section{Elsö eset}

Á. L. 2017-ben, 2 hónaposan biliaris atresia miatt Kasaimútéten esett át. Kivizsgálása során szerológiai és PCRvizsgálattal igazolt cytomegalovirusfertőzés miatt ganciklovirkezelésben részesült. 2018 júliusában, 14 hónaposan 'split' (parciális) máj transzplantációján esett át Hamburgban. A standard ellátás részeként szisztémásszteroid-, takrolimusz-, aszpirin- és urzodezoxikólsav-terápia indult. 3,5 hónappal a transzplantációt követően a korábbi drén helyén tályog alakult ki, mely a fistulajárat sebészi megnyitása és parenteralis antibiotikum alkalmazása mellett gyógyult. A transzplantációt követő 8. hónapban az Epstein-Barr-vírus emelkedett, a vér mononukleáris sejtjeiben a felső határérték 9-szeresének megfelelő DNS-kópiaszámát tapasztaltuk, emiatt a szisztémásszteroid-terápiát leállítottuk, a takrolimusz dózisát csökkentettük. Ezt követően a fenti érték a normáltartományhoz kezdett közeledni.

2019 júliusában, egy évvel a transzplantációt követően a gyermeknél orrvérzés, véres székletek jelentkeztek, laboreredményeiben anaemia, thrombocytopenia, mérsékelten megnyúlt INR, ismételten emelkedett EpsteinBarr-vírus-kópiaszám látszódott. Hasi ultrahangvizsgála- 
tán bélfal-megvastagodás ábrázolódott, hasi MR-vizsgálaton több helyen diffúziógátlás látszódott, a csontvelö-mintavétel azonban malignitást nem igazolt. A panaszok hátterében a coeliakiát, az infektív ágenst kizártuk, de az etiológiát a pánendoszkópia, az exploratív laparotomia és a vett bioptátumok szövettani elemzése sem tudta megállapítani. A panaszok jelentkezését követően 2 hónappal a kapszula-endoszkópia előkészítéseként elvégzett (ismételt) felső-alsó endoszkópián azonban a nyálkahártya típusos eltérései voltak láthatók, a szövettani vizsgálat pedig Crohn-betegség fennállását igazolta. 5-ASA (5-aminoszalicilsav)-terápia mellett a beteg panaszai szúntek.

\section{Második eset}

H. S. biliaris atresia miatt 2003-ban, 2,5 hónaposan Kasai-mútéten esett át. 2015-ben, 12 évesen vascularisan dekompenzált májelégtelenség miatt 'split' máj transzplantációjára került sor. Immunszuppresszióként szteroid-, takrolimusz-, MMF-terápiában részesült, az utóbbit azonban erőteljes viszketés miatt fél évvel a bevezetését követően leállítottuk. Egy évvel a transzplantációt követően rejectio alakult ki; kétszer is részesült szteroid-lökésterápiában, a MMF-terápiát visszavezettük. Ekkor már gyakori alhasi fájdalomra, tenesmusra panaszkodott, napi 3-4 alkalommal volt laza széklete, a kolonoszkópos vizsgálat azonban a panaszokat magyarázó eltérést nem igazolt.

A májgraft elégtelen múködése és cholestasis miatt 3 évvel az első transzplantációt követően retranszplantáció történt. Egy hónappal később akut rejectio miatt szteroid-lökésterápia indult, elégtelen válasz miatt azonban 2 ciklusban anti-timocitaglobulin-kezelésre szorult.

A retranszplantációt követően, 10 hónappal később, 2018. júliusban fáradékonyság, hasmenés jelentkezett, a széklet kalprotektinszintje emelkedett volt. A pánendoszkópia és a szövettani vizsgálat Crohn-betegség fennállását igazolta, terápiáját 5-ASA-terápiával egészítettük ki.

\section{Harmadik eset}

B. Á. polycystás vese, juvenilis nephronophthisis szövődményeként kialakult végstádiumú veseelégtelenség miatt 2005-ben, 9 évesen kadáver donoros vesetranszplantáción esett át. A mütét kapcsán hepatitis C-vírus-fertőzöttsége igazolódott. Anamnéziséből kiemelendő a szomatropinterápiát igénylő növekedési elmaradottsága, a csontdeformitást okozó, korrekciós mütéteket igénylő rachitise és 4 éves korában femurosteotomiája.

2013 áprilisában, 17 évesen kezdődtek véres székletei, ennek hátterében először fissura ani, fél évvel később az ismétlődő vérzés hátterében nodus haemorrhoidalis igazolódott. Két hónappal később, 2013 decemberében tenesmus, napi 6-10 alkalommal jelentkező lágy széklet és fogyás miatt további vizsgálatok indultak. Ekkor székle- tében vér nem volt, laboreredményeiben thrombocytosis, emelkedett CRP, hypoalbuminaemia és anaemia látszódott, az enteralis infekció fennállását kizártuk. Hasi ultrahangvizsgálaton a colon területén bélfal-megvastagodás látszódott. A kolonoszkópia és a szövettani vizsgálat a poszttranszplantációs lymphoproliferativ betegséget és a cytomegalovirusfertőzést kizárta, a panaszok, a tünetek és az elvégzett vizsgálatok alapján Crohn-colitis igazolódott. A panaszok szteroid- és 5-ASA-kezelés mellett szûntek; a MMF-kezelést AZA-terápiára váltották, felnőttgondozásba történó átadása is e mellett a terápia mellett történt.

\section{Negyedik eset}

H. Á.-t 2016 márciusában, 10,5 évesen Crohn-beteg materből származó vesével transzplantálták, biopsziával igazolt Denys-Drash-szindróma (nephrosisszindróma és nemi szervi eltérés) miatt. A transzplantációt követően takrolimusz- és mikofenolátterápia indult. Anamnéziséből kiemelendő 4 éves korában történt mútétje phimosis és cryptorchismus miatt, melynek során a bal oldalon sem a scrotumban, sem inguinalisan nem találtak hereszövetet. Testvére nem besorolható IBD (IBD-unclassified, IBD-U) miatt áll gondozás alatt.

15 hónappal a transzplantációt követően rotavírus-enteritise zajlott, ezt követően továbbra is rendszeresen jelentkezett hasi fájdalma és 1-1 hígabb széklete. 2017 októberében napi 6-7 alkalommal jelentkező híg vizes széklet, fogyás miatt jelentkezett. A mikofenolát dózisát csökkentették, széklettenyésztése kórokozót nem igazolt. Laboratóriumi értékeiben thrombocytosis, emelkedett CRP, hypoalbuminaemia, alacsony vasszint és ASCA-pozitivitás látszódott. Székletében a vér vizsgálata pozitív lett, emellett magas széklet-kalprotektinszint igazolódott. Pánendoszkópos és szövettani vizsgálata IBD-re utalt, pontos típusa nem volt meghatározható. Kizárólagos enteralis táplálás indult, együttmúködési nehézség miatt azonban szisztémás szteroidra váltottunk. Ezzel párhuzamosan a mikofenolátkezelés leállt, AZAterápia indult. Később terápiáját 5-ASA-terápiával egészítették ki, mely mellett panaszai megszüntek.

Az esettanulmányokhoz kapcsolódó összesítő adatokat és a vizsgálatok pontos eredményeit az 1. és a 2. táblázatban összesítettük.

\section{Megbeszélés}

Esetbemutatásainkban 4 (2 máj- és 2 vesetranszplantáción átesett) beteget mutattunk be, akiknél szolidszervtranszplantációt követően jelentkező véres széklet, illetve hasmenés hátterében de novo IBD igazolódott. A vizsgált populációban a de novo IBD incidenciája - más külföldi tanulmányokhoz hasonlóan [7] - igen magasnak, 1\%-nak bizonyult. Összehasonlításképpen: a HUPIR (Hungarian Paediatric IBD Registry) adatai alapján a gyermekkori IBD hazai előfordulása 7,48/105, 
1. táblázat |Az esetekhez kapcsolódó adatok részletezése

\begin{tabular}{|c|c|c|c|c|}
\hline & 1. eset & 2. eset & 3. eset & 4. eset \\
\hline Alapbetegség & Biliaris atresia & Biliaris atresia & Polycystás vese & $\begin{array}{l}\text { WTl-mutáció, Denys- } \\
\text { Drash-szindróma }\end{array}$ \\
\hline Társbetegség & Nincs & Nincs & $\begin{array}{l}\text { Rachitis, pes planoval- } \\
\text { gus, növekedési } \\
\text { elmaradottság, krónikus } \\
\text { HCV-fertőzés }\end{array}$ & Nincs \\
\hline Transzplantáció & 'Split' máj transzplantációja & 'Split' máj transzplantációja & $\begin{array}{l}\text { Kadávervese transzplan- } \\
\text { tációja }\end{array}$ & $\begin{array}{l}\text { Élődonoros vesetransz- } \\
\text { plantáció (Crohn-beteg } \\
\text { mater) }\end{array}$ \\
\hline Életkor a transzplantációkor & 14 hónap & 12, majd 14 év & 8,5 év & 10 év \\
\hline $\begin{array}{l}\text { A transzplantációt követő } \\
\text { immunszuppresszív terápia }\end{array}$ & Szteroid, takrolimusz & $\begin{array}{l}\text { Szteroid, takrolimusz, } \\
\text { MMF }\end{array}$ & $\begin{array}{l}\text { Szteroid, takrolimusz, } \\
\text { MMF }\end{array}$ & Mikofenolát, takrolimusz \\
\hline $\begin{array}{l}\text { A transzplantáció és az } \\
\text { IBD-re utaló tünetek } \\
\text { jelentkezése között eltelt idő }\end{array}$ & 12 hónap & $\begin{array}{l}3 \text { év (az elsô transzplantáci- } \\
\text { óhoz képest) }\end{array}$ & 8,8 év & 14 hónap \\
\hline Tünetek & $\begin{array}{l}\text { Hematochesia, vashiányos } \\
\text { anaemia }\end{array}$ & $\begin{array}{l}\text { Hasmenés, fáradékonyság, } \\
\text { végbéltáji fájdalom, } \\
\text { csípő́ízületi fájdalom, } \\
\text { perianalis fissura, tenesmus }\end{array}$ & $\begin{array}{l}\text { Hasmenés, fogyás, } \\
\text { tenesmus }\end{array}$ & Hasmenés, fogyás \\
\hline $\begin{array}{l}\text { Terápia a tünetek jelentkezé- } \\
\text { sekor }\end{array}$ & $\begin{array}{l}\text { Takrolimusz, UDCA, ASA, } \\
\text { K-, D-vitamin, Fe }\end{array}$ & $\begin{array}{l}\text { Takrolimusz, MMF, } \\
\text { szteroid, ASA, UDCA, } \\
\text { pantoprazol }\end{array}$ & $\begin{array}{l}\text { Takrolimusz, MMF, } \\
\text { szteroid, famotidin, } \\
\text { allopurinol, darbepoe- } \\
\text { tin-alfa, B-vitamin- } \\
\text { komplex, } \mathrm{NaHCO}_{3}, \mathrm{Fe}\end{array}$ & $\begin{array}{l}\text { Takrolimusz, mikofeno- } \\
\text { lát, famotidin, ASA, } \\
\text { metoprolol, allopurinol, } \\
\mathrm{Mg}, \mathrm{Fe}\end{array}$ \\
\hline $\begin{array}{l}\text { A tünetek és a diagnózis } \\
\text { között eltelt idő }\end{array}$ & 2 hónap & 8 hónap & 1,5 hónap & 7 hónap \\
\hline Életkor az IBD diagnózisakor & 2 év & 15,5 év & 17,5 év & 12 év \\
\hline $\begin{array}{l}\text { IBD miatt megkezdett } \\
\text { gyógyszeres terápia }\end{array}$ & 5-ASA & 5-ASA & $\begin{array}{l}\text { Szteroid, 5-ASA, AZA } \\
\text { (a MMF leállt) }\end{array}$ & $\begin{array}{l}\text { Kizárólagos enteralis } \\
\text { táplálás, szteroid, AZA, } \\
\text { 5-ASA (a mikofenolát } \\
\text { leállt) }\end{array}$ \\
\hline
\end{tabular}

5-ASA = 5-aminoszalicilsav; ASA = aminoszalicilsav; AZA = azatioprin; Fe = vas; $\mathrm{HCV}=$ hepatitis $\mathrm{C}$-vírus; IBD = gyulladásos bélbetegség; Mg = magnézium; MMF = mikofenolát-mofetil; UDCA = urzodezoxikólsav; WT = Wilms-tumor

melyen belül $4,72 / 10^{5}$ a Crohn-betegség és $2,32 / 10^{5}$ a colitis ulcerosa [9].

Összegezve az eseteket elmondhatjuk, hogy a kivizsgálást indikáló főbb tünetek a haematochesia, a hasmenés, a fáradékonyság, és a fogyás voltak, melyek a transzplantációt követó $1-8,8$ év során jelentek meg. 1 betegnél 3 percentilis alatti súly- és hosszpercentilis volt jellemzó a diagnóziskor, de ez a beteg már korábban, az IBD tüneteinek jelentkezését megelőzően növekedési elmaradottság miatt növekedésihormon-terápiát kapott. Thrombocytosist, CRP-emelkedést és hypoalbuminaemiát a vesetranszplantált betegeknél tapasztaltunk. A hasi ultrahangvizsgálaton 2 esetben látszódott bélfalmegvastagodás. 1 betegnél ASCA-pozitivitás volt jelen, bár nem mindegyik betegnél történt ASCA és ANCA irányában is vizsgálat. A betegség lokalizációját tekintve leginkább a vastagbél volt érintett, ezt követte a terminalis ileum. A szövettani vizsgálat 2 betegnél írt le granulomát. Az IBD kialakulása előtt a poszttranszplantációs időszakban takrolimuszkezelésben mindegyik, MMFkezelésben 3 beteg részesült. Az IBD diagnózisát köve- tően a továbbiakban mindegyik betegnél fenntartó kezelésként meszalazint alkalmaztak. A korábban vesetranszplantáción átesett gyermekeknél a MMF-kezelést AZA-terápiára állították át.

A de novo IBD etiológiája egyelőre még tisztázatlan. Feltételezik az immunszuppresszió mint infekcióra hajlamosító tényező szerepét. Bakteriális infekció esetén a terápiaként adott antibiotikumok dysbiosishoz vezetnek, majd csökkentik a bélben a barrier funkciót. A virális infekciók közül kiemelkedő a cytomegalovirus szerepe - előfordulása az ép immunitású egyének között is kimagasló, szervátültetések kapcsán pedig az egyik legfontosabb infekciós szövődmények közé tartozik a cytomegalovirusreaktiváció [10]. Cytomegalovirusfertőzéskor megnő a bélpermeabilitás, indukálódik a l-es típusú vascularis sejtadhéziós molekula (vascular cell adhesion molecule-1, VCAM1), amely facilitálja a fehérvérsejtek kitapadását az endotheliumra, végső soron pedig a colon mikrocirkulációja romlásnak indul [2]. A cytomegalovirussal fertőzött endothelialis sejtek képesek stimulálni a T-sejtek IL2-termelését, elindítva a gyulladásos folyama- 
2. táblázat |A kivizsgálások eredményei

\begin{tabular}{|c|c|c|c|c|}
\hline & 1. eset & 2. eset & 3. eset & 4. eset \\
\hline \multicolumn{5}{|l|}{ Növekedési elmaradottság } \\
\hline Súly (kg és percentilis) & $13,5(75-90)$ & $64,5(3-10)$ & $32(10)$ & $32,5(<3)$ \\
\hline $\begin{array}{l}\text { Magasság } \\
\text { (cm és percentilis) }\end{array}$ & $92(90-97)$ & $159(3-10)$ & $159(<3)$ & $147(25-50)$ \\
\hline \multicolumn{5}{|l|}{ Radiológia } \\
\hline $\begin{array}{l}\text { Hasi ultrahang- } \\
\text { vizsgálat }\end{array}$ & $\begin{array}{l}5 \mathrm{~mm} \text {-es bélfalvastagság } \\
\text { elsősorban a sigma } \\
\text { területén }\end{array}$ & Kóros eltérést nem írt le & $\begin{array}{l}\text { A colon területén } \\
12 \text { mm-es falvastagság, } \\
\text { nyirokcsomó-duzzanat }\end{array}$ & $\begin{array}{l}\text { IBD-re utaló eltérést nem } \\
\text { írt le }\end{array}$ \\
\hline Hasi MR-vizsgálat & $\begin{array}{l}\text { Diffúziógátlás a mesen- } \\
\text { terialis nyirokcsomókban, } \\
\text { a duodenum falában, egy } \\
\text { ileocaecalis bélkacsban, } \\
\text { a medenceövet alkotó } \\
\text { csontokban, a femurfejek- } \\
\text { ben, több csigolyatestben } \\
\text { és csigaívben }\end{array}$ & Nem történt & Nem történt & Nem történt \\
\hline \multicolumn{5}{|l|}{ Labor } \\
\hline $\mathrm{CRP}(\mathrm{mg} / \mathrm{l})$ & 9,5 & 0,7 & 135,9 & 50,4 \\
\hline $\mathrm{Fe}(\mu \mathrm{mol} / \mathrm{l})$ & - & 15 & - & 2 \\
\hline Albumin $(\mathrm{g} / \mathrm{l})$ & 36 & 45 & 26 & 31 \\
\hline $\operatorname{Thr}(\mathrm{G} / \mathrm{l})$ & 118 & 118 & 486 & 544 \\
\hline $\operatorname{Hbg}(\mathrm{g} / \mathrm{l})$ & 87 & 133 & 75 & 112 \\
\hline $\operatorname{vvt}(\mathrm{T} / \mathrm{l})$ & 4,1 & 4,9 & 2,7 & 4,4 \\
\hline Htk \% & 28,0 & 38 & 23 & 33 \\
\hline Kalprotektin & & 424 & & $>1800$ \\
\hline Immunszerológia & $\begin{array}{l}\text { Coeliakia: negatív } \\
\text { (a többit nem nézték) }\end{array}$ & $\begin{array}{l}\text { Citoplazma elleni AT, } \\
\text { ds-DNS elleni AT, } \\
\text { májspecifikus proteinek } \\
\text { elleni AT-pozitivitás. }\end{array}$ & Nem történt & ASCA-IgG-pozitivitás \\
\hline Az endoszkópia képe & $\begin{array}{l}\text { A rectumban aphták, a } \\
\text { nyálkahártya hyperaemiás, } \\
\text { szakaszosan ödémás, } \\
\text { vérzékeny }\end{array}$ & $\begin{array}{l}\text { A gyomorban erozív } \\
\text { gyulladás, a Bauhin-billen- } \\
\text { tyưn egy aphtosus fekély, } \\
\text { helyenként erythemás } \\
\text { bélszakaszok }\end{array}$ & $\begin{array}{l}\text { Csőszerû vastagbél, } \\
\text { a területén aphtás } \\
\text { fekélyek, pseudopolyposis }\end{array}$ & $\begin{array}{l}\text { Diffúz gastritis és duodeni- } \\
\text { tis, a colonban aphtás } \\
\text { fekélyek, torzult haustratio } \\
\text { és pseudopolyp, a jobb } \\
\text { colonfélben és a coecumban } \\
\text { mély ulcusok; a terminalis } \\
\text { ileumban fekélyes gyulladás }\end{array}$ \\
\hline Szövettani vizsgálat & $\begin{array}{l}\text { A colon descendens és } \\
\text { transversum területén } \\
\text { granulomaképződés, } \\
\text { a terminalis ileumban } \\
\text { idült gyulladás; duodenitis }\end{array}$ & $\begin{array}{l}\text { A colon teljes területén } \\
\text { cryptaabscessusok, a colon } \\
\text { descendensben granuloma }\end{array}$ & $\begin{array}{l}\text { A szöveti kép a leginkább } \\
\text { Crohn-betegségnek } \\
\text { feleltethető meg, bár a } \\
\text { teljes szöveti spektrum } \\
\text { nem látható }\end{array}$ & $\begin{array}{l}\text { A coecumban és a colon } \\
\text { descendensben kifekélyese- } \\
\text { dett, gyulladt granulációs } \\
\text { szövet }\end{array}$ \\
\hline A gyulladás lokalizációja & Pancolitis & Pancolitis & Colitis & $\begin{array}{l}\text { Terminalis ileum és felső } \\
\text { gastrointestinalis traktus }\end{array}$ \\
\hline IBD a családban & Nem volt & Nem volt & Nem volt & $\begin{array}{l}\text { Mater: Crohn-beteg; } \\
\text { testvér: IBD-U }\end{array}$ \\
\hline
\end{tabular}

AT $=$ antitest ASCA $=$ Saccharomyces cerevisiae elleni antitest CRP $=$ C-reaktív protein; ds-DNS = kettős szálú dezoxiribonukleinsav; IBD $=$ gyulladásos bélbetegség; IBD-U = „nem besorolható” IBD; Hbg = hemoglobin; Htk = hematokrit; IgG = immunglobulin-G; MR = mágneses rezonancia; thr $=$ thrombocyta; $\mathrm{vvt}=$ vörösvértest

tokat [11]. A fenti 4 betegnél cytomegalovirusfertőzés mindössze 1 esetben fordult elő, a transzplantációt megelőző időszakban.

A de novo IBD etiológiáját tekintve az alkalmazott immunszuppresszív terápia szerepe is komoly kérdéseket vet fel. Ismert a MMF vastagbélgyulladás-szerü képet kialakító mellékhatása [6, 7], egyes tanulmányokban azonban a takrolimuszt is mint IBD-re hajlamosító szert jelölik meg. A kalcineurininhibitorok közé tartozó szer az IL2-produkciót gátolja. Az IL2 hiánya T-sejt-diszregulációt okozhat, ez pedig a szuppresszív immunválasz hiányához, csökkent mértékéhez vezet, végső soron pedig szerepet játszik a vastagbélgyulladás kialakulásában [2]. Ezt támasztja alá az a kutatás, melyben IL2-deficiens egerekben colitis kialakulását figyelték meg [12]. Annak ellenére, hogy a takrolimusz és a ciklosporin-A 
(CyA) is gátolja az IL2-képződést, szerepüket a de novo IBD kialakulásában eltérő mértékűnek véleményezi az irodalom. Vesetranszplantált betegek esetében a takrolimusszal kezelt csoportban alacsonyabb IL2-expresszáló T-sejt-számot találtak a CyA-val kezelt csoporthoz képest [13]. Takrolimusszal kezelt patkányokban alacsonyabb ILl0-szintet írtak le a CyA-val kezelt csoporthoz képest [14], továbbá egy 74 éves, szívtranszplantáció miatt takrolimusszal kezelt nő esetében a kezelés mellett észlelt multiplex fekélyek miatt történt terápiaváltás CyA-ra az ulceratiók megszúnését okozta [15]. A fentiek ellenére egy tanulmányban arról számolnak be, hogy a konzervatív terápiára rezisztens IBD-ben szenvedő betegek ötödében a takrolimusz remissziót indukált; fontos azonban megjegyezni, hogy ez a tanulmány igen kis esetszámú volt [16]. Habár az eddigiek alapján a CyA biztonságosabbnak tünik a de novo IBD kialakulása szempontjából, VCAMl - és CyA-terápia mellett is megfigyeltek 10 évvel a transzplantációt követően kialakuló de novo IBD-t [17].

A de novo IBD diagnózisát megnehezíti a gyakran atípusos klinikai megjelenés. Transzplantált betegekben a hasi panaszok és a vastagbélgyulladás hátterében előfordul, hogy nem tudnak ismert okot azonosítani, így a diagnózis idiopathiás colitis marad. Feltételezhető azonban, hogy a transzplantációt követő immunszuppresszáns szerek hatására a gyakoribb opportunista infekciók indítják el az IBD kialakulását, azonban a diagnózishoz szükséges szöveti szintű elváltozások az immunszuppresszió miatt maszkírozódnak, ezzel meghiúsítva a megbízható diagnózist, de fenntartva a tüneteket [18]. Észben kell tartani, hogy a hasi panaszok hátterében pszichoszomatikus tünetek is állhatnak [19]. Egy nagyszámú, gyermekkori esetekkel foglalkozó tanulmány azt is felveti, hogy a jelenleg de novo IBD-ként kezelt betegség valójában egy, az IBD-hez nagyon hasonló, de igazából önálló entitás [7].

Érdekes, hogy sem az általunk gondozott tüdőtranszplantált betegekben nem alakult ki de novo IBD, sem az irodalomban nem találni erre példát. Az immunszuppresszív terápiákkal, hatásmechanizmusukkal, az általuk jelentett rizikófaktorokkal kapcsolatban mindenképpen további vizsgálatok szükségesek, hogy a betegek a lehető legbiztonságosabb terápiát kapják a rejectio megelőzését és az immunszuppresszió által okozott kockázatokat tekintve.

\section{Következtetés}

A jelen esettanulmány során retrospektív módon összesítettük transzplantált betegeink közül a szövettani vizsgálattal megerősített de novo IBD-vel diagnosztizált eseteket. Elmondható, hogy amellett, hogy mindegyik beteg részesült legalább egy olyan immunszuppressziós terápiában, amely az irodalom alapján de novo IBD kialakulására hajlamosít, egyéb rizikófaktorok is jelen voltak, mint például korábbi cytomegalovirusfertőzés, a gastrointesti- nalis traktust érintő mütétek, antibiotikumterápiák, IBD a családi anamnézisben. Szükség lenne azonban nagyobb esetszámú, prospektív vizsgálatokra, hogy a de novo IBD lefolyásáról és etiológiájáról többet tudjunk meg. Addig is fontos megjegyezni, hogy tekintettel arra, hogy a prezentációs tüneteknek megfelelő, a differenciáldiagnosztika során felmerülő egyéb betegségek (bakteriális, virális infekció, protozoonfertőzés, gyógyszerasszociált hasmenés, graft versus host betegség, poszttranszplantációs lymphoproliferativ betegség, ischaemiás colitis, coeliakia, microvascularis ischaemiás colitis, vastagbélrák) terápiája merőben eltér, a de novo IBD diagnózisa és a megfelelő terápia hozzájárulhat a transzplantált betegek morbiditásának és mortalitásának csökkentéséhez [3].

Anyagi támogatás: A cikk megírása anyagi támogatásban nem részesült.

Szerzôi munkamegosztás: B. K. K.: A nemzetközi irodalom áttekintése, a tanulmány írása, szerkesztése. K. K., R. Gy., S. P. és Sz. A.: A vesetranszplantált betegek áttekintése, a betegekkel kapcsolatos adatok összesítése. D. A.: A tanulmány írásának szervezője, vezetője. A közlemény végleges változatát valamennyi szerző elolvasta és jóváhagyta.

Érdekeltségek: A szerzőknek nincsenek érdekeltségeik.

\section{Köszönetnyilvánítás}

A szerzők köszönettel tartoznak a Semmelweis Egyetem I. Gyermekgyógyászati Klinikáján minden dolgozónak, aki részt vesz a gyulladásos bélbetegségben szenvedő és szervtranszplantált gyermekek ellátásában.

\section{Irodalom}

[1] Zhang YZ, Li YY. Inflammatory bowel disease: pathogenesis. World J Gastroenterol. 2014; 20: 91-99.

[2] Verdonk RC, Haagsma EB, van den Berg AP, et al. Inflammatory bowel disease after liver transplantation: a role for cytomegalovirus infection. Scand J. Gastroenterol. 2006; 41: 205-211.

[3] Nepal S, Navaneethan U, Bennett AE, et al. De novo inflammatory bowel disease and its mimics after organ transplantation. Inflamm Bowel Dis. 2013; 19: 1518-1527.

[4] Hampton DD, Poleski MH, Onken JE. Inflammatory bowel disease following solid organ transplantation. Clin Immunol. 2008; 128: $287-293$

[5] Wörns M, Lohse A, Neurath M, et al. Five cases of de novo inflammatory bowel disease after orthotopic liver transplantation. Am J Gastroenterol. 2006; 101: 1931-1937.

[6] Dalle IJ, Maes BD, Geboes KP, et al. Crohn's-like changes in the colon due to mycophenolate? Colorectal Dis. 2005; 7: 27-34.

[7] Fernandes MA, Braun HJ, Evason K, et al. De novo inflammatory bowel disease after pediatric kidney or liver transplant. Pediatr Transplant. 2017; 21 : e.12835.

[8] Dezsőfi A, Reusz Gy, Kovács L, et al. Solid organ transplantation in childhood. [Szervtranszplantáció gyermekkorban.] Orv Hetil. 2018; 159: 1948-1956. [Hungarian]

[9] Müller KE, Lakatos PL, Arató A, et al. Incidence, Paris classification, and follow-up in a nationwide incident cohort of pediatric 
patients with inflammatory bowel disease. J Pediatr Gastroenterol Nutr. 2013; 57: 576-582.

[10] Sinkó J. Current treatment modalities of immunocompromised patients with cytomegalovirus infection. I. Epidemiological and clinical perspectives. [Aktualitások a sérült immunitású betegek cytomegalovirusinfekcióinak ellátásában. I. Epidemiológia és klinikai szempontok.] Orv Hetil. 2019; 160: 83-92. [Hungarian]

[11] Waldman WJ, Adams PW, Orosz CG, et al. T lymphocyte activation by cytomegalovirus-infected, allogeneic cultured human endothelial cells. Transplantation 1992; 54: 887-896.

[12] Sadlack B, Merz H, Schorle H, et al. Ulcerative colitis-like disease in mice with a disrupted interleukin-2 gene. Cell 1993; 75 : 253-261

[13] Haagsma EB, van den Berg AP, Kleibeuker JH, et al. Inflammatory bowel disease after liver transplantation: the effect of different immunosuppressive regimens. Aliment Pharmacol Ther. 2003; 18: 33-44.

[14] Jiang H, Wynn C, Pan F, et al. Tacrolimus and cyclosporine differ in their capacity to overcome ongoing allograft rejection as a result of their differential abilities to inhibit interleukin-10 production. Transplantation 2002; 73: 1808-1817.
[15] Pan D, Shaye O, Kobashigawa JA. Tacrolimus-associated diffuse gastrointestinal ulcerations and pathergy: a case report. Transplant Proc. 2017; 49: 216-217.

[16] Thin LW, Murray K, Lawrance IC. Oral tacrolimus for the treatment of refractory inflammatory bowel disease in the biologic era. Inflamm Bowel Dis. 2013; 19: 1490-1498.

[17] Harms B, Bremner AR, Mulligan J, et al. Crohn's disease postcardiac transplantation presenting with severe growth failure and delayed onset of puberty. Pediatr Allergy Immunol. 2004; 15: 186-189.

[18] Wahbeh G, Hupertz V, Hallowell S, et al. Idiopathic colitis following cardiac transplantation: three pediatric cases. Pediatr Transplantation 2003; 7: 464-468.

[19] Fehér P, Annár D, Zsákai A, et al. The prevalence of psychosomatic complaints among 8-17-year-old Hungarian children. [Pszichoszomatikus tünetek előfordulási gyakorisága 8-17 éves magyar gyermekek körében.] Orv Hetil. 2019; 160: 464-472. [Hungarian]

(Boros Kriszta Katinka dr., Budapest, Bókay J. u. 53., 1083 e-mail: boros.kriszta@med.semmelweis-univ.hu)

\section{PÁLYÁZATI FELHÍVÁS \\ Gyöngyös Városi Önkormányzat pályázatot hirdet Felnőtt háziorvosi feladatok ellátására}

Gyöngyös városában a gyöngyösi I. számú felnőtt háziorvosi körzetben vállalkozási formában, határozatlan idöre szóló feladatellátási szerződés keretében heti 40 órában, a felnőtt háziorvosi feladatok ellátásához kapcsolódó ügyeleti ellátásban történő részvétel vállalásával, a Nemzeti Egészségbiztosítási Alapkezelő által kötött szerződés szerinti közvetlen finanszírozással, a Gyöngyös, Diósmalom u. 41. szám alatti háziorvosi rendelő és a rendelő tárgyi eszközeinek használatával.

A körzet 2019. február 1-töl tartósan betöltetlen háziorvosi körzetnek minősül, ezért külön támogatás igényelhető a NEAK-tól.

Pályázati feltételek:

- 4/2000. (II. 25.) EüM rendeletben meghatározott képesités,

- 18/2000. (II. 25.) Korm. rendeletben elöírt egyéb feltételek megléte,

- részletes szakmai önéletrajz,

- végzettséget igazoló okmányok másolata,

- OONYI kárty másolata,

- érvényes MOK tagsági kártya megléte,

- 3 hónapnál nem régebbi erkölcsi bizonyítvány,

- hozzájárulás a pályázati anyag elbírálásában résztvevők betekintési jogához.

A pályázat benyújtásának határideje: a felhívás megjelenésétől számított 30 nap.

A pályázat elbírálásának határideje:

a benyújtási határidőt követő soros Képviselö-testületi ülés.

A pályázat benyújtásának módja:

- személyesen vagy postai úton Gyöngyös Városi Önkormányzat, Hiesz György polgármester részére (3200 Gyöngyös, Fő tér 13.) történő átadásával/megküldésével,

- a kizárólag elektronikus úton történő jelentkezés érvénytelennek minősül.

A feladat ellátásának időpontja:

a feladat legkorábban a Képviselö-testület döntését követő megegyezés szerint, de legkésőbb 4 hónap elteltével látható el.

További felvilágosítás kérhető:

Gyöngyösi Közös Önkormányzati Hivatal Közigazgatási és Intézményirányítási lgazgatóság: dr. Horváth Gábor igazgatótól a 06-37/510-329 telefonon vagy személyesen elözetes időpont-egyeztetést követően.

A cikk a Creative Commons Attribution 4.0 International License (https://creativecommons.org/licenses/by/4.0/) feltételei szerint publikált Open Access közlemény, melynek szellemében a cikk bármilyen médiumban szabadon felhasználható, megosztható és újraközölhető, feltéve, hogy az eredeti szerző és a közlés helye, illetve a CC License linkje és az esetlegesen végrehajtott módositások feltüntetésre kerülnek. (SID_1) 